\title{
All that Glitters is Not Always Gold or Silver: Typical Bilateral Investments Treaties (BITs) Clauses as Peril to Third World Economic Sovereignty
}

\author{
By George Forji Amin
}

\begin{abstract}
Modern BITs habitually begin with a preamble, whereupon basic concepts such as what constitutes an investment and an investor for the purpose of the treaty are somewhat defined. The effectiveness and manner in which BITs pursue their objectives are remarkably uniformed, thanks to their vigorous investors-friendly provisions (although they sometimes use slightly varied expressions), which are also highlighted at length. The most common provisions include National treatment (NT), Most Favoured Nation clause (MFN), Fair and Equitable Treatment (FET), and Disputes Settlement Mechanisms (DSM). These clauses together constitute the core of the treaty rights, thus, they end up affecting the general equilibrium of the treaties. The uniformity of the provisions is primarily due to model BITs by developed countries and standard BITs developed by International Organisations such as the OECD, both of which are a codification of longstanding disputed norms of customary international law.
\end{abstract}

Keywords: Bilateral Investment Treaties (BITs); Disputes Settlement Mechanisms (DSM Fair and Equitable Treatment (FET); National treatment (NT); Most Favoured Nation clause (MFN)

\section{Introduction}

The flight of capital from one country to another is nothing new. However, rules governing the entire regime of International Investment have expanded considerably since the end of the Second World War, thanks to Bilateral Investment Treaties (BITs) between home states of investors (Home State) and the state hosting the investment (Host State). ${ }^{1}$ The significance of this development is the stimulation of legal mechanisms to protect assets of investors in foreign countries. ${ }^{2}$

BITs must be understood within the context of the huge interest attached to the inflows of Foreign Direct Investments (FDI) by developing countries during the last three decades. These countries have essentially reached a broadening consensus that attracting FDI inflows would result to gross investments leading to economic growth and development. Given the competitive nature of FDI, many of them have pinned their hopes on BITs as a means of bridging the wide

\footnotetext{
*Research Fellow and Adjunct Lecturer in International Law, Faculty of Law, University of Helsinki, Finland. E-mails: aminforji@gmail.com or amingeorges@ yahoo.co.uk or amin.forji@ helsinki.fi. ${ }^{1}$ Hamilton \& Rochwerger (2005) at 2; Newcombe \& Paradell (2008) at 11.

${ }^{2}$ Hamilton \& Rochwerger (2005); Newcombe \& Paradell (2008) at 11.
} 
development gap with the developed world. It is expected that a demonstrative commitment to investment protection would eventually improve their chances in the worldwide competition for foreign direct investment (FDI). ${ }^{3}$ Despite a modest start, BITs have emerged as universally accepted legal instruments for the promotion and protection of Foreign Investment. ${ }^{4}$

The first BIT was signed in 1959 between former West Germany and Pakistan. ${ }^{5}$ More BITs have been signed in the last fifteen years than the preceding three decades. ${ }^{6}$ The extent of their proliferation has been extraordinary, as has been their clauses, thus making them one of the most remarkable recent developments in contemporary international law. The United Nations Conference on Trade and Development (UNCTAD) has estimated that BITs reached a record number of 2608 in 2008, up from 2,495 in 2005, with over 1,891 entering into force. This number makes BITs the largest group of any kinds of treaties, past and present. ${ }^{7}$ This is remarkable given that only 75 BITs were signed in the 1960s. The number increased to 167 and 389 in the '70s and '80s respectively. ${ }^{8}$ In terms of countries, just 2 countries signed BITs in the 1950s. That number steadily increased to 48 in the 1960s, 69 in the 1970s, 102 in the 1980s and 173 by the end of the 1990s. ${ }^{9}$ At the same time, International Centre for Settlement of Investment Disputes (ICSID) registered 182 investment arbitrations between 1973 and $2007 .^{10}$

BITs clauses are largely pro-investor standards of treatment, with expressive promises, for instance that foreign investors would be treated fairly and equitably, in a non-discriminatory manner vis-à-vis the domestic investors, and/ or on a Most-Favoured nation basis, and most importantly that in the event of disputes, the investors would have a right to direct recourse against the host state. ${ }^{11}$ Consequently, it is not only the number of BITs that are on the rise, but the numbers of countries involved as well as a corresponding surge in investor-tostate disputes.

This paper seeks to demonstrate that despite the mad rush for BITs, they nonetheless come with baggage for host states. The agreements accord foreign investors the right to directly sue host states for alleged violations of any of the treaty's investment protection provisions, ${ }^{12}$ that is, a strong recognition of nonstate actors. The clause is considered to be the most economically important aspect of BITs. The ability of private parties who invest abroad to address a judicial recourse against an offending host state has historically been dependent

\footnotetext{
${ }^{3}$ Busse, Königer \& Nunnenkamp (2010) at 147; Kurtz (2002) at 723.

${ }^{4}$ Robin (1984) at 931.

${ }^{5}$ The Treaty between the Federal Republic of Germany and Pakistan for the Promotion and Protection of Investments (Germany v. Pakistan (1959)), 457 U.N.T.S. 23.

${ }^{6}$ Vandevelde (1996) at 545.

${ }^{7}$ Greig, Annacker \& Zaide, (2008) at 257. See generally UNCTAD 2008.

${ }^{8}$ Neumayer \& Spess (2005) at 1569.

${ }^{9}$ Hamilton \& Rochwerger (2005) at 6.

${ }^{10}$ Convention on the Settlement of Investment Disputes between States and Nationals of Other States (ICSID), (1965)

${ }^{11}$ Yackee (2009) at 1554; Guzman, Elkins \& Simmons (2006); Nash (1993) a4 433.

${ }^{12}$ Franck (2005) at 1522-1523; Carlos (2004) at 304-305.
} 
on their home governments willingness to plead on their behalf, through a diplomatic channel. Consequently private investment disputes were turned into political issues. ${ }^{13}$ With almost every modern BIT now providing for a dispute settlement mechanism through the $\mathrm{ICSID}^{14}$, consenting to the treaties is tantamount to developing countries undermining the independence, sovereignty and control that they have historically fought so hard to protect.

It is clear that the political independence of developing countries even in the third millennium has not translated into economic independence. Studies on the effects of BITs on developing countries have been conflicting. While some have concluded that the treaties in fact have positive effects on FDI inflows ${ }^{15}$, others have indicated that the effect is little, negligent or insignificant. ${ }^{16}$ Whichever way we look at the situation, the one thing that has become obvious is the fact that the inflow of FDI into developing countries is conditioned on the latter sacrificing their sovereignty for credibility. ${ }^{17}$ Thanks to their stringent provisions, BITs tend to function as facilitators par excellence in stabilising this unusual relationship. They are for lack of a better expression, instruments of Economic Hegemony.

\section{Examining Typical BITs Clauses}

The mad rush of BITs by the third world is revealing of how far these countries have deviated from their past, transcending from their suspicions of the FDI regime to enthusiastically embracing investment liberalization. Such a liberal thinking has facilitated "the adoption of similar investment protection provisions and international law formulas, which stipulate the extent and type of compensation in the event of expropriation."18

Despite the uniformity of the clauses, they exhibit such a high level of ambiguity as to fail to mean one and the same thing. Consequently, in order to grasp what National Treatment, Most Favoured Nation, Fair and Equitable Treatment and Dispute Settlement clauses really stand for, it would be imperative to separate their literal meaning from their practical intent. For instance, literally, national treatment implies that foreign investors may not be treated any worse than national investors in the same line of business. Both case law and academic scholarships have however suggested that in actual sense, the foreign investors are expected to be treated better (and often are) than the national investors. ${ }^{19}$

\footnotetext{
${ }^{13}$ Goodman (2007) at 455, 457. (Explaining how investors previously had little ability to country court access. Their ability depended on their home governments).

${ }^{14}$ Convention on the Settlement of Investment Disputes between States and Nationals of Other States (ICSID), (1965), 575 United Nation Treaty Series (U.N.T.S) 159, 4 Int'l Legal Materials 524 (1965).

${ }^{15}$ Neumayer \& Spess (2005) at 1571-3; Salacuse \& Sullivan (2005) at 67-71.

${ }^{16}$ Tobin \& Rose-Ackerman (2005).

${ }^{17}$ See generally Guzman (1998).

${ }^{18}$ See Chalamish (2009) at 324.

${ }^{19}$ See Neumayer \& Spess (2005) at 1570. See also Marvin Roy Feldman Karpa v. United Mexican States, ICSID Case No. ARB(AF)/99/1, (16 December 2002).
} 
Although dubbed as "common goals" of the signatories, BITs provisions in real sense are far from being neutral. Most of the provisions are aligned with investors' interests and pay little regard to the sovereignty of the host nation. ${ }^{20}$ Consequently, the foreign investors end up enjoying not only higher security but better treatment than the domestic investors. ${ }^{21}$ Developing countries generally sign the treaties from a vulnerable angle, with very limited, if any negotiating power. ${ }^{22}$ With neighbours and fellow developing countries all competing for the same FDI for economic growth, the extent to which host states are sacrificing their sovereignty for credibility is enormous. ${ }^{23}$ Consequently, virtually any public policy regulation by the host state can potentially be challenged whenever foreign investors construe it to affect them. ${ }^{24}$ Given the ambiguity of BITs clauses, there is a high tendency that host states might become susceptible to several arbitration proceedings to which they have not necessarily agreed. ${ }^{25}$ It follows that the undefined aspects of BITs clauses are just as relevant as their stated function.

\section{Fair and Equitable Treatment Provision}

To many, the tendency would be to qualify the defunct 1948 Havana charter for an International Trade Organization (ITO) as long dead and buried. Such an assertion could be valid from a purely restrictive point of view. If we however take a holistic approach, it would be observed that even though the body of the obsolete treaty has truly been buried, its soul was never. In fact, the ghost of one of its remnant clauses: "Just and Equitable Treatment" has very much been alive, and even evolve to become a central part of international investment protection. Under the ITO, the concept was used as a tool for the promotion of bilateral or multilateral agreements on measures designed to assure Just and Equitable Treatment for the enterprise, skills, capital, arts and technology brought from one member country to another. ${ }^{26}$ Despite the collapse of the ITO negotiations, the clause has been subsequently revived and reshaped through various legal instruments. ${ }^{27}$ It has been invoked at virtually every multilateral negotiation on

\footnotetext{
${ }^{20}$ See Vandevelde (1998) at 514.

${ }^{21}$ See Neumayer \& Spess, (2005) at 1570.

${ }^{22}$ See Chung (2007).

${ }^{23}$ See generally, Guzman (1998).

${ }^{24}$ See Neumayer \& Spess (2005) at 1571.

${ }^{25}$ See Chalamish (2009) at 333.

${ }^{26}$ See Article II (2), 1948 Havana Charter for an International Trade Organization.

${ }^{27}$ Despite some variations in form and content, the clause has been adopted by various international instruments, most notably: the 1948 ninth International Conference of American States, Bogota (Article 22), the US treaties on FNCs, the 1959 Draft Convention on Investments Abroad, the 1967 OECD Draft Convention on the Protection of Foreign Property (Article 1 (a)), and the North Atlantic Free Trade Agreement (NAFTA, Article 1105). Like the ITO, most of these instruments have flopped as well. Article 11 (2)(i) of the ITO stipulated that the Organisation would assure "Just and Equitable Treatment for the Enterprise, skills, Capital, Arts and Technology brought from one member country to another." The draft OECD Convention on the Protection of Foreign Property, 1967, in its Article 1(a) titled "Treatment of Foreign Property", provided that "Each party shall at all times ensure Fair and Equitable
} 
investment. It is however in modern BITs that the concept has surged in popularity, under a new nomenclature: "Fair and Equitable Treatment" (FET). Host states are required to provide Fair and Equitable Treatment to the investments and investors of the other treaty party. ${ }^{28}$

Despite the "beguiling simplicity" 29 of the phrase and its widespread usage, what constitutes "Fair" and "Equitable" treatment remains vague and elusive, thus providing space for a host of different interpretations. It is often stated together with other standards. However, unlike those other standards which are relative in character (National Treatment and Most Favoured Nation clauses), Fair and Equitable Treatment is an absolute, non-contingent standard, implying that its exact meaning can only be determined by reference to the specific circumstances of application. ${ }^{30}$ It is at the centre of virtually every BIT arbitration. Infect, a recent UNCTAD study reveals that FET remains the most relied upon and successful basis for a treaty claim. All 13 investment decisions that were rendered in 2008 on their merits for example had a claim based on FET that was addressed by the tribunal. $^{31}$ The vagueness and expansiveness of the concept has led tribunals, government officials and scholarly commentators to arrive at conflicting conclusions regarding the interpretation of its normative content. What does Fair and Equitable Treatment as a legal concept require of host states when engaging with foreign Investors? ${ }^{32}$ Is the standard measured against Customary International Law Minimum Standard, a more expansive international law standard or is it a self contained independent principle that is additional to general international law?

Meanwhile most of the debate has oscillated between FET as synonymous to the minimum standard of protection required by international law and the concept as an autonomous self-contained principle, yet another school of thought has opined that the FET is a deliberate delegation of authority to investment tribunals to autonomously and actively develop standards of fairness and equitableness for international investment relations. ${ }^{33}$ It is assumed that this flexibility and vagueness is essential in order to give arbitrators the possibility to articulate a range of principles necessary to achieve the treaty's purpose in a given case. ${ }^{34}$ Given the growing number of BITs arbitral awards examining claims of host states' denial of FET, the implication of each of these discussions could be very broad.

The minimum standard of protection has been the object of tensions between the developed and developing countries. The standard is to the effect that foreign

\footnotetext{
Treatment to the property of the nationals of the other parties. It shall accord within its territory the most constant protection and security to such property and shall not in any way impair the management, maintenance, use, enjoyment or disposal thereof by unreasonable or discriminatory measures.

${ }^{28}$ See Kill (2007) at 834.

${ }^{29}$ See McLachlan, Shore \& Weiniger (2007); cf. Malnik (2009). "Fairness" and "Equity" and fundamental principles recognized by virtually every legal system.

${ }^{30}$ See Yannaca-Small (2004) at 2.

${ }^{31}$ UNCTAD 2009 a 8.

${ }^{32}$ See Tudor (2009) at 236. See also Schreuer (2005).

${ }^{33}$ Brower (2003).

${ }^{34}$ See Yannaca-Small (2004) at 2.
} 
investors are entitled to a minimum level of treatment, and any treatment which falls short of this standard would give rise to international responsibility on the part of the violating state. ${ }^{35}$ The classic application of the concept has been traced to the $20^{\text {th }}$ century case of Neer V. Mexico $(1926)^{36}$, which posited that the treatment of an alien, in order to constitute an international delinquency, "should amount to an outrage, to bad faith, to wilful neglect of duty, or to an insufficiency of governmental action so far short of international standards that every reasonable and impartial man would readily recognize its insufficiency."37 Although this paradigm has long stood out as an articulation of customary international law, some tribunals have recently observed that the standard has since evolved. ${ }^{38}$ It has been shaped by the conclusion of FCNs and BITs, all of which largely and concordantly "provide for Fair and Equitable Treatment and for full protection and security for the foreign investor and his investment." Even if there was once a cloud of doubt over the minimum standard of treatment as a norm of customarily international law, this is no longer the case, given the global proliferation of BITs. Considering that the minimum standard of protection is now an acceptable international legal standard, it can be deduced that if it is synonymous to FET as suggested by some scholars ${ }^{40}$, then it goes without saying that the parties actually intended to impose a stricter standard than that reflected in customary law.

I find the above thesis tying FET to the minimum standard to be unconvincing and the suggestion that FET is an autonomous concept and a deliberate delegation of authority to investment tribunals to actively develop standards of fairness and equitableness for international investment relations to be persuasive. A closer observation of BITs illustrate that in the absence of a clear indication to the contrary, FET is intended to stand as an independent concept. If parties to a BIT intended an observance of minimum standard of protection, they would have referred to it as such, instead of using a different expression. ${ }^{41}$ According to F.A. Mann, who clearly supported FET as an independent concept:

\footnotetext{
${ }^{35}$ See Yannaca-Small (2004) at 8.

${ }^{36}$ See LFH Neer \& Pauline Neer (USA) v. United Mexican States (1926) IV RIAA 60. The facts of this case are that Paul Neer, a US citizen was murdered in Mexico. The US government accused its Mexican counterpart of showing a total lack of diligence to investigate and prosecute the crime. A joint US-Mexico General Claims Commission was charged with laying down a uniform standard of protection.

${ }^{37}$ Ibid

${ }^{38}$ See for example, Mondev International Ltd $v$. United States, Award, ICSID Case No $A R B(A F) / 99 / 2$; IIC 173, (2002) (hereinafter Mondev case). Also, in the Pope \& Talbot case ( Pope \& Talbot V. Canada, Award, April 10th 2001, 7 ICSID Reports, 102), the tribunal observed that the ICJ in the ELSI case had since moved away from the Neer formulation by replacing the requirement of "every reasonable and impartial person" with a higher threshold of investor protection against the state conduct.

${ }^{39}$ See Mondev case, para 125.

${ }^{40}$ See for instance Gann (1985); Paterson (1991).

${ }^{41}$ See Schreuer (2005) at 360. Schreuer posits that it would be unlikely for a BIT to use FET to denote a well-known concept such as the minimum standard of treatment in customary international law. See also UNCTAD 1999, at 3-28.
} 
The terms 'Fair and Equitable treatment' envisage conduct which goes far beyond the minimum standard and afford protection to a greater extent and according to a much more objective standard than any previously form of words. A tribunal would not be concerned with a minimum or maximum or average standard. It would have to decide whether in all circumstances the conduct in issue is fair and equitable or unfair and inequitable. No standard defined by other words is likely to be material. The terms are to be understood and applied independently and autonomously. ${ }^{42}$

Being an autonomous independent concept, FET can as the case may be, normally complement, incorporate or overlap with the minimum standard of treatment. The relationship between FET and the minimum standard of protection is succinctly illustrated in Article 1105(1) of the North American Free Trade Agreement (NAFTA).The section reads thus:

\section{"Article 1105: Minimum Standard of Treatment}

1. Each party shall accord to investments of investors of another party treatment in accordance with international law, including Fair and Equitable Treatment and full protection and security. ${ }^{, 43}$

At least two features stand out from this provision. Although it is captioned as "Minimum standard of treatment", it mentions FET as an additional standard ("including Fair and Equitable Treatment"), and not as a synonym to the Minimum Standard of Treatment. The caption "Minimum standard of treatment" is also suggestive of a direct reference to international law, implying that FET is an additional requirement to the general standard required by customary international law. It's mentioning under the "Minimum standard of treatment" without further explanation however seems to be a deliberate delegation of authority to investment tribunals to actively develop standards of fairness and equitableness for international investment relations on a case-by-case basis.

The main characteristics of FET is thus its flexibility in allowing the tribunal to "evaluate and balance the circumstances of the case in front of him before applying the standard and its sanction [...] using intuition and expertise"44 Tudor observes that FET actually has no standard or fixed content. ${ }^{45}$ How can a standard with no standard and without a fixed content, one wonders, become a norm of customary international law? I consider Tudor's assertion to be an overstatement of the ambiguity contiguous to FET. Although FET does not come across as a traditional "rule" of international law, it nonetheless stands out as a veritable "standard". It is articulated in such a way that arbitrators can always exploit its flexibility in every given case to give it meaning. The tribunal in the Mondev case explicitly stated that a judgment of what is fair and equitable "cannot be reached in the abstract: it must depend on the facts of the particular case." 46

\footnotetext{
${ }^{42}$ Mann (1981) at 244. Cf. Schreuer (2005) at 360.

${ }^{43}$ Article 1105 (1) of NAFTA, 33 I.L.M (1993), p. 639.

${ }^{44}$ See Tudor (2009) at 120.

${ }^{45}$ See Tudor (2009) at 133.

${ }^{46}$ See Mondev International Ltd v. United States, Award, ICSID Case No ARB(AF)/99/2; IIC 173, (2002), para 118.
} 
In Pope \& Talbot v. Canada $(2001)^{47}$, the tribunal found that the requirement of "Fair and Equitable Treatment" in Article 1105 of the North American Free Trade Agreement (NAFTA) was not limited to customary international law (minimum standard of treatment), but rather additional to the requirements of international law. ${ }^{48}$ Given its broad nature, the mere fact that a host state has breached a rule of international law would weigh heavily in finding a breach of FET. $^{49}$

\section{National Treatment Clause}

Modern BITs typically recognise the ability of a host state to restrict the access of foreign investors only within the contours of domestic regulatory framework. ${ }^{50}$ A National Treatment clause thus requires host states to accord to foreign investors the same treatment that it accords its nationals in similar circumstances. ${ }^{51}$ Accordingly, the host state cannot discriminate amongst investors based on nationality. The clause is the first of the two pillars on non-discrimination (the other being Most-Favoured Nation Clause). ${ }^{52}$ In principle the aim of the provision is to promote investment neutrality through the provision of a level playing field for foreign investors in the post-establishment phase. In practice however, it is just another loaded concept shrouded in ambiguity. At least one tribunal has ruled that a discriminatory measure is one that fails to provide for national treatment. ${ }^{53}$ The ruling has however failed to indicate whether the two standards are identical. There is no obligation under Customary International Law requiring host states to treat foreign investors in the same way as they treat nationals. ${ }^{54}$

Technically-speaking, National Treatment is supposed to have a very narrow application, since it is generally required only where the foreign investor and the domestic investor find themselves in identical or similar circumstances/ situations. ${ }^{55}$ However, despite its prevalence in BITs, the phrase "similar

\footnotetext{
${ }^{47}$ Pope \& Talbot V. Canada, Award, April 10th 2001, 7 ICSID Reports, 102, paras 105-118

${ }^{48}$ Chapter XI of the agreement regulates the operation of BITs in the region.

${ }^{49}$ See Schreuer (2005) at 364

${ }^{50}$ See Adlung \& Molinuevo (2008) at 379

${ }^{51}$ See Dolzer \& Stevens (1995) at 63. See also UNCTAD 2005 at. 32. See also Article 1102 (2) of NAFTA, which provides thus:

"Each Party shall accord to investments of investors of another Party treatment no less favorable than it accords, in like circumstances, to investments of its own investors with respect to the establishment, acquisition, expansion, management, conduct, operation, and sale or other disposition of investments."

${ }^{52}$ See Trebilcock \& Giri (2004)

${ }^{53}$ See Ronald S. Lauder v. The Czech Republic, Final Award, $3^{\text {rd }}$ Sep. 2001, 9 ICSID Reports, para. 220.

${ }^{54}$ See Brownlie (2008) at 524-528. Cf. Brown (2009) at 64.

${ }^{55}$ Examples of the stipulation abound. Article 2 of the Turkey-Nigeria BIT reads thus:

"Each party shall accord to these investments, once established, treatment no less favourable than that accorded in similar situation to investments of its investors or to investments of investors of any third country, whichever is the most favourable". Article 3 (1) of the UK-Belize BIT (1982) provides that: "Neither contracting party shall in its
} 
circumstances" or "similar situations" or "like circumstances" remains unclear and is still open to a wide variety of interpretations in the abstract and in the context of a particular dispute. Does it imply that the domestic investor must be doing exactly the same business as the foreign investor, or similar activity, or is it dependent on the country's investment code? What differential treatment would amount to a violation of National Treatment? Must it be a difference in law (de jure) or simply a difference in effect (de facto) $?^{56}$ Which policies of the host state may justify a differential treatment between the foreign investor and the domestic investor? ${ }^{57}$

Existing case law has neither been consistent on the issue nor has it answered all the above questions. Tribunals have generally applied the standard differently, depending on whether they have understood "like circumstances" to be restrictive or elastic in nature. Where a restrictive view has been taken, the tribunal has asserted that "in like circumstances" refers to the same line of business. ${ }^{58}$ In other situations, an elastic interpretation has been advanced, for instance, that considering the natural wide connotation attributed to "like circumstances" it goes without saying that the concept extends to commercially competitive economic and business sectors. ${ }^{59}$ One major difference between the cases is that while the Marvin Roy Feldman tribunal requires a mere evidence of discrimination to proof nationality-based discrimination, a much higher standard is expected under the S.D. Myers ruling. ${ }^{60}$

territory subject investments or returns of nationals or companies of the other contracting party to treatment less favourable than that which it accords in the same circumstances to investments or returns of its own nationals."

Article 2(2) of the US-Senegal BIT (1983) talks of "treatment not less favourable than that which it accords in like situations to investments and associated activities of its own nationals or companies". See also Article 1102 (2) of NAFTA.

${ }^{56}$ See Mann \& von Moltke (2004).

${ }^{57}$ See Dolzer (2005).

${ }^{58}$ See for example, Marvin Roy Feldman Karpa v. United Mexican States, ICSID Case No. $A R B(A F) / 99 / 1$, (16 December 2002), para. 171. (Consequently, the tribunal suggested that violation could be applicable if the investment involved the same business, that is, the export of cirgarettes).

${ }^{59}$ See for instance: S.D. Myers Inc. v. Canada, First Partial Award of November 13, 2000 (Hunter, Chiasson, Schwartz), 40 ILM 1408 (2001), para. 250. The tribunal stated thus:

"The Tribunal considers that the interpretation of the phrase "like circumstances" in Article 1102 must take into account the general principles that emerge from the legal context of the NAFTA, including both its concern with the environment and the need to avoid trade distortions that are not justified by environmental concerns. The assessment of "like circumstances" must also take into account circumstances that would justify governmental regulations that treat them differently in order to protect the public interest. The concept of "like circumstances" invites an examination of whether a non-national investor complaining of less favourable treatment is in the same "sector" as the national investor. The Tribunal takes the view that the word "sector" has a wide connotation that includes the concepts of "economic sector" and "business sector". (Para 250).

${ }^{60}$ The Marvin Roy Feldman in para. 181 took the following position:

"it is not self-evident, as the Respondent argues, that any departure from national treatment must be explicitly shown to be a result of the investor's nationality. There is no such language in Article 1102. Rather, Article 1102 by its terms suggests that it is sufficient to show less favourable treatment for the foreign investor than for domestic investors in like circumstances[...]For practical as well as legal reasons, the Tribunal is prepared to assume 
Since the situations of the foreign investor and the domestic investor are rarely identical, it has been observed that the application of the National Treatment provision may well be a difficult task. ${ }^{61}$ It still leaves a few unanswered questions. For example, how would the concept apply where both the domestic and the foreign investors are both subject to unfair treatment from the host state? Does the concept come on the defence of both investors or does it apply selectively for the benefit of the foreign investor? Does the clause involve a comparison with the average national or a wealthy national? Although there are no clear-cut answers to these questions, it can nonetheless be implied from the general reading of the provision that in any event, the real interpretation of national treatment means that the foreign investor has to be treated better than the domestic investor, whenever they find themselves in similar situations. This is because he is naturally entitled to all the benefits enjoyed by domestic investor as well as any other rights that the host state may have contracted with investors of third countries. ${ }^{62}$

\section{Most Favoured Nation (MFN) Clause}

Modern BITs generally contain some form of Most Favoured Nation (MFN) provision. The clause typically seeks to extend to foreign investors of one contracting state treatment which is not less favourable than that which the host state accords to nationals of any other third country. ${ }^{63}$ Soon after the Second World War, there were some calls for a clarification of the scope of MFN clauses in International treaties. ${ }^{64}$ The International Law Commission (ILC) responded by

that the differential treatment is a result of the Claimant's nationality, at least in the absence of any evidence to the contrary."

On the Contrary, the S.D. Myers tribunal ruled that "Intent is important, but protectionist intent is not necessarily decisive on its own. The existence of an intent to favour nationals over nonnationals would not give rise to a breach of Chapter 1102 of the NAFTA if the measure in question were to produce no adverse effect on the non-national complainant. The word "treatment" suggests that practical impact is required to produce a breach of Article 1102, not merely a motive or intent that is in violation of Chapter 11". (para. 254).

${ }^{61}$ See Dolzer \& Stevens (1995) at 63

${ }^{62}$ See MFN Clause below. Article 3 (1) of the UK-Belize BIT (1982) for instance provides that: "Neither contracting party shall in its territory subject investments or returns of nationals or companies of the other contracting party to treatment less favourable than that which it accords in the same circumstances to investments or returns of its own nationals."

${ }^{63}$ See Dolzer \& Stevens (1995) at 65. See also Schill (2009) at 502, and see also Trebilcock \& Howse, (2005) at 49. As a sine qua non, more favourable treatment must be accorded to a third state for the MFN provision to be invoked, since the rights of the beneficiary state are derived from the treaty between the granting state with a third state. The clause has been used since the $12^{\text {th }} \mathrm{C}$. Its genesis is traced to a 1226 treaty in which King Frederick II conceded the privileges previously afforded to Pisa and Genoa to the city of Marseilles. It was subsequently used to prevent discrimination in International Trade. (See Radi, 'The application of the most favoured nation clause to the dispute settlement provisions of bilateral investment treaties: Domesticating the Trojan Horse' 18 EJIL, (2007), pp. 757, 759, See also Freyer \& Herlihy (2005),

${ }^{64}$ See Ziegler (2008), 'Most-Favoured Nation (MFN) Treatment', in: Reinisch (ed.), Standards of Investment Protection, (2008), pp. 29-86. Cf. Ziegler (2010) at 77. 
adopting the so-called Draft Articles on the Most Favoured Nation Clause (ILC Draft Articles) during its $30^{\text {th }}$ session in 1978. According to Article 4, "[A] Most Favoured Nation clause is a treaty provision whereby a state undertakes an obligation towards another state to accord most favoured nation treatment in an agreed sphere of relations." ${ }^{\circ 65}$ Article 5 is more explicit. It defines the provision as "treatment accorded by the granting state to the beneficiary state, or to persons or things in a determined relationship with that state, not less favourable than treatment extended by the granting state to a third state or to persons or things in the same relationship with that third state." ${ }^{, 66}$ If for instance, Finland and Cameroon sign a BIT with an MFN clause, France which although not a contracting party to this BIT but having signed a similar treaty with Cameroon can rely on one of Finland-Cameroon BIT clauses which accords extra protection to Finnish investors. Similarly, Finnish investors can depend on the extra protections in the France-Cameroon BIT. In this case, each of the treaties establishes the judicial link between the beneficiary state and the third state. ${ }^{67}$

As in the case of National Treatment, the MFN provision is significant because it out rightly prohibits discrimination on the basis of nationality or source of origin of the investment, thus purportedly allowing investors to claim ensuring an efficient allocation of resources. ${ }^{68}$ It has however been observed that the clause is a break from general international law and its bilateralist rationale because in principle, it "permits States to accord differential treatment to different States and their nationals and instead ensure equal treatment between the State benefiting from MFN treatment and any third State." 69

Although the standard is credited for creating "an equality of competitive opportunities" between the different foreign investors, it has also been observed that it also "limits the host countries' room for manoeuvre with respect to future investment agreements, as it obliges the host country to unilaterally extend to investors from treaty partners any additional rights that it grants to third countries in future agreements". ${ }^{70}$ Theoretically, BITs are treaties involving just two countries, thus citerus paribus (everything being equal) should exhibit a bilateral character. But as has been noted before, the treaties are unique in that their provisions necessarily lead to international ramifications. As a result, a MFN provision is also a source of international obligation other than those included in the basic treaty. ${ }^{71}$

\footnotetext{
${ }^{65}$ See Article 4, ILC Draft Articles on Most Favoured Nation Clause, $30^{\text {th }}$ Session, $8^{\text {th }}$ May-28 $8^{\text {th }}$ July 1978, Supplement No. 10, Doc A/33/10, 2 Y.B of I.L.C. (1978), 8. It is worth noting that the ILC suspended its work on the issue after this adoption.

${ }^{66}$ Ibid

The US Model BIT in the relevant section provides that "Each party shall accord to investors of the other party treatment no less favourable than that it accords, in like circumstances, to investors of any non-party with respect to the establishment, acquisition, expansion, management, conduct, operation, and sale or other disposition of investments in its territory..." (See Article 4, U.S. Model Bilateral Investment Treaty, (2004)).

${ }^{67}$ See Houde, (2004) at 9.

${ }^{68}$ Ranjan (2007) at 67. See also Vesel (2007) at 141.

${ }^{69}$ See Schill (2009) at 502.

${ }^{70}$ See UNCTAD 1999.

${ }^{71}$ See Ziegler (2010) at 79
} 
Since the MFN provision naturally necessitates two separate BITs, it is always imperative for tribunals to first of all determine the basic treaty that contains the MFN from the third party treaty. In the Anglo- Iranian Oil Company $\operatorname{case}^{72}$, the International Court of Justice (ICJ) determined that the basic treaty is that containing the Most-Favoured Nation Provision. In the words of the Court, the treaty containing the Most Favoured Nation clause is

"[...] the treaty which establishes the juridical link between the United Kingdom (the beneficiary state) and the third party treaty and confers upon that state the rights enjoyed by the third party. A third party treaty, independent of and isolated from the basic treaty, cannot produce any legal effect as between the United Kingdom (the beneficiary state) and Iran (the granting state): It is res inter alios acta" ${ }^{\text {,73. }}$.

In other words, the MFN clause is contained in the basic treaty, meanwhile the more favourable treatment is found in the third party treaty. ${ }^{74}$

For the MFN provision to be applied, the object of the basic treaty and the third party treaty must not be different in nature.

It is worth noting that it is entirely permissible under customary international law for states to freely enter into bilateral quid pro quo bargains that extend preferential treatment to the other contracting party. ${ }^{75}$ The MFN provision seemingly stands out to prohibit this practice. Is this a constructive or regrettable shift? Is the MFN clause therefore an absolute provision? Is the clause limited to substantive treatment or extends to dispute settlement as well? That is, can foreign investors invoke the MFN clause to establish jurisdiction over investment disputes with host states? ${ }^{76}$

The scope of the MFN provision with respect to dispute settlements under BITs has in recent years become a point of interest for both arbitrators and legal scholars, whose divergence in opinion have raised rather more questions than answers about the correct interpretation of the standard. ICSID tribunals have in particular taken conflicting positions on whether investors can rely on the MFN provision to invoke the dispute resolution provisions of a third party BIT that are comparatively more favourable to the investor. ${ }^{77}$ The problem has been addressed in Maffezini, Salini, Siemens and Plama cases (amongst other cases) with seemingly divergent decisions. ${ }^{78}$ Despite the divergences, the cases nonetheless highlight an attempt to harmonize investors' rights as well as a

\footnotetext{
${ }^{72}$ Anglo-Iranian oil Co. (U.K. v. Iran), July 22 1952, I.C.J, p. 93.

${ }^{73}$ See para. 109.

${ }^{74}$ See generally Gaillard (2005).

${ }^{75}$ See Ziegler (2010) at 79.

${ }^{76}$ See Fietta (2005).

${ }^{77}$ See Wong (2008) at 173.

${ }^{78}$ Emilio Agustion Maffezini V. Kingdom of Spain, ICSID Case No. ARB/97/7, Decision of January 25, 2000;

Salini Construttori S.p.A and Italstrade S.p.A V. The Hashemite Kingdom of Jordan, ICSID Case No. ARB/02/13, Decision of November 15, 2004; Siemens A.G. V. The Argentina Republic, ICSID Case No. ARB/O2/8, Decision of August 3, 2004; Plama Consortium Limited V. Republic of Bulgaria, ICSID Case No. ARB/03/24, Decision of February 8, 2005.
} 
reaffirmation of the quasi-multilateral aspect of BITs. ${ }^{79}$ While Maffezini and Siemens tribunals determined that MFN clauses apply to dispute settlement provisions, the tribunals in Salini and Plama on the other hand ruled that MFN clauses in BITs were not intended to extend to dispute settlement provisions.

\section{Maffezini v. Kingdom of Spain $^{80}$}

The Maffezini case concerned a dispute between the State of Spain and an Argentine investor, Mr. Emilio Agustin Maffezini, regarding the latter's investment in an enterprise called EAMSA (specialised in the production and distribution of chemical products in the Spanish region of Galicia). Having set up his business under the Spain-Argentina BIT, he later sought the application of the MFN clause contained in Article IV (2) ${ }^{81}$ of the said treaty, so that he could benefit from the more favourable provision in the 1991 Spain-Chile BIT. Unlike the Spain-Argentina BIT that required a preliminary waiting period of eighteen (18) months for the exhaustion of local remedies before any referral to an ICSID tribunal in case of disputes, a corresponding Spain-Chile BIT allowed investors to opt for international arbitration after a six months negotiation period. ${ }^{82}$ The contention of Maffezini was that since Spain accorded Chilean investors more favourable treatment than Argentine investors, in the absence of any exceptions, it can be deduced from the Spain-Argentina BIT that the MFN clause was intended to give Argentine investors the option to benefit from the more favourable treatment enjoyed by other foreign investors (Chilean investors) in this case). ${ }^{83}$ Upon determining that the claimant had satisfied the ejusdem generis standard, ${ }^{84}$ the tribunal sustained most of Maffezini's claims while at the same time rejecting Spain's argument that the application of the MFN clause was limited to substantive matters of treatment to investors and did not cover procedural or jurisdictional questions. ${ }^{85}$ In the opinion of the tribunal,

Notwithstanding the fact that the basic treaty [...] does not refer expressly to dispute settlement as covered by the Most Favoured Nation clause, the Tribunal considers that there are good reasons to conclude that today dispute settlement arrangements are inextricably related to the protection of foreign investors. ${ }^{86}$

As a result, it reached the conclusion that:

\footnotetext{
${ }^{79}$ See Chalamish (2009) at 324.

${ }^{80}$ See Emilio Agustion Maffezini V. Kingdom of Spain, ICSID Case No. ARB/97/7, Decision of January 25, 2000.

${ }^{81}$ Article IV is to the effect that "In all matters subject to this agreement, this treatment shall not be less favourable than that extended by each Party to the investments made in its territory by investors of a third country".

${ }^{82}$ See Article 10 (2) of the Spain-Chile BIT.

${ }^{83}$ Maffezini Para. 40

${ }^{84}$ This principle requires that the MFN attracts only matters belonging to the same subject matter as that to which the clause itself relates. (See Commission of Arbitration in the Ambatielos case, U.N. Reports of Int'l Arbitral Awards, 1963, 107).

${ }^{85}$ Maffezini, Paras 53, 64.

${ }^{86}$ Ibid, Para 54.
} 
If a third party treaty contains provisions for the settlement of disputes that are more favourable to the protection of the investors' rights and interests than those of those in the basic treaty, such provisions may be extended to the beneficiary of the Most Favoured Nation clause, as they are fully compatible with the ejusdem generis principle. ${ }^{87}$

In rendering the decision, the tribunal mostly based its verdict on the language of the BIT, such as possible intent of the parties, the policies and economic considerations that shaped the parties negotiations, as well as the practice of the Spanish government in concluding its BITs. ${ }^{88}$ Meanwhile the MFN clauses explicitly provide for the provisions on dispute settlement in some BITs, in many others, it merely outline various rights contained in the agreement without actually making any mention of dispute settlement. ${ }^{89}$ Even in the latter cases, silence would not necessarily imply non-existence. In fact, the Maffezini tribunal drew a clear distinction between the "legitimate extension of rights and benefits by means of the operation of the [MFN] clause, on the one hand, and disruptive treaty-shopping that would play havoc with the policy objectives of underlying specific treaty provisions, on the other hand". ${ }^{90}$ Despite its ruling in favour of Maffezini, it nonetheless warned that investors must not be allowed to override public policy considerations that the "contracting parties might have envisaged as fundamental conditions for their acceptance of the agreement in question." 11

\section{Siemens A.G. V. The Argentina Republic ${ }^{92}$}

The situation and the ruling in Siemens are both similar to that in the Maffezini case. The tribunal was faced with the question whether foreign investors could initiate arbitration after a six months negotiation period as stipulated in the Chile-Argentina BIT or do that only after the exhaustion of local remedies during an 18 months period as required in the German-Argentina BIT. The tribunal found in favour of a claimant who relying on the Maffezini case sought to avoid the application of the 18 months waiting period by invoking the third party treaty with Chile. Unlike the Maffezini case, the wording of the MFN clause did not allow for more favourable treatment as regards all matters related to the basic treaty. ${ }^{93}$ Despite the narrowness in formulation, the tribunal

\footnotetext{
${ }^{87}$ Ibid, Para 56.

The tribunal determined that the total amount of compensation and interests that Spain must pay Maffezini sums up to 58 million Spanish Pesetas. (See Paras 33, 97).

${ }^{88}$ Maffezini Para. 42. See also Chalamish (2009), at 327.

${ }^{89}$ See Houde (2004) at 13.

${ }^{90}$ Maffezini, Para 63.

${ }^{91}$ Ibid Para. 62.

${ }^{92}$ See Siemens A.G. V. The Argentina Republic, ICSID Case No. ARB/02/8, Decision of August 3, 2004.

${ }^{93}$ Siemens Para. 31.

Article 3 of the Germany-Argentina BIT read thus: “(1) Neither Contracting Party shall subject investments in its territory by or with the participation of nationals or companies of the other Contracting Party to treatment less favourable than it accords to investments of its own nationals or companies or to investments of nationals or companies of any third State. (2)
} 
took an understanding that this was a mere distinction without a difference, hence determining that the dispute settlement provisions were well within the scope of the MFN provision. ${ }^{94}$ As it noted, the basic treaty contained

"[...] as a distinctive feature, special dispute settlement mechanisms not normally open to investors. Access to these mechanisms is part of the protection offered under the treaty. It is part of the treatment of foreign investors and investments and of the advantages accessible through an MFN clause [...]. The term 'treatment' and the phrase 'activities related to the investments' are sufficiently wide to include settlement of disputes." 95

Salini Construttori S.p.A and Italstrade S.p.A v. The Hashemite Kingdom of Jordan ${ }^{96}$

Adopting a rather different approach from the Maffezini and Siemens jurisprudence, the tribunal in Salini V. Jordan found that MFN clauses of the applicable BIT were not intended to extend to the dispute settlement provisions, on the basis of the specific language of that clause. The case involved a dispute arising out of the construction of the Karameh dam in Jordan by two Italian companies. The Italian claimants sought to bring contractual claims against Jordan before the ICSID tribunal, despite their prior agreement to first exhaust local remedies, on the ground that Jordan's BITs with the USA and UK allowed American and British investors to invoke arbitration, and by the same token, the MFN clause in the Italy-Jordan BIT "naturally" entitled Italian investors to enjoy the same procedural treatment. ${ }^{97}$

Article 9 (2) provided that

"In case the investor and an entity of the Contracting Parties have stipulated an investment Agreement, the procedure foreseen in such investment agreement shall apply." 98 The MFN clause in the Italy-Jordan BIT provided that "both Contracting Parties, within the bounds of their own territory, shall grant investments effected by, and the income accruing to, investors of the Contracting Party no less favourable treatment than that accorded to investments effected by, and income accruing to, its own nationals or investors of Third States."

\footnotetext{
Neither Contracting Party shall subject nationals or companies of the other Contracting Party, as regards their activity in connection with investments in its territory, to treatment less favourable than it accords to its own nationals or companies or to nationals or companies of any third State."

${ }^{94}$ Siemens para. 184.

${ }^{95}$ Ibid Paras 102, 103.

${ }^{96}$ See Salini Construttori S.p.A and Italstrade S.p.A V. The Hashemite Kingdom of Jordan, ICSID Case No. ARB/02/13, Decision of November 15, 2004.

${ }^{97}$ Article IX of the Italy-Jordan BIT (Agreement on the Promotion and Protection of Investments, Italy-Jordan, July 21, 1999) specifically referred contractual disputes to Jordanian domestic courts. See also Salini, Para. 36.

${ }^{98}$ See Article 9 (2) of the Italy-Jordan BIT.

${ }^{99}$ See Article 3 of the Italy-Jordan BIT.
} 
The tribunal observed that Article 3 of the Italy-Jordan BIT was silent on the application of the MFN clause to the dispute settlement mechanism. ${ }^{100} \mathrm{It}$ then made an important distinction between MFN provisions that expressly provide for dispute settlement from those that do not. ${ }^{101}$ Unlike the situations in Maffezini and Siemens, the Italy-Jordan BIT did not contain a provision envisaging "all rights" or "all matters" covered by the agreement.

The jurisprudence laid down in Maffezini and Siemens is to the effect that the intent of the parties is absolute; therefore, the interpretation of the MFN clause should not defeat public policy concerns. As far back as the Ambatielos case (1956), the ICJ observed that "the question is whether the consent given by the parties...to arbitrate a certain category of disputes [ ] does or does not extend to the [claimant's] claim."102

Based on this caveat, the Salini tribunal determined that the common intention of the parties was clearly not to have the MFN provision apply to dispute settlement mechanism. ${ }^{103}$ In the words of the tribunal:

Quite on the contrary, the intention as expressed in Article 9(2) of the BIT was to exclude from ICSID jurisdiction contractual disputes between an investor and an entity of a State Party such that such disputes might be settled in accordance with the procedures set forth in the investment agreements. ${ }^{104}$

Given that the Salini V. Jordan tribunal asserted jurisdiction only on claims based on the violations of the treaty but declined jurisdiction over contractual claims, it goes without saying that the burden of proof rested on the claimant to proof such matters of treaty practice by the host state. ${ }^{105}$ In Maffezini case, it was the expansively worded nature of the MFN clause that convinced the tribunal that the parties actually intended the provision to have a broad application. ${ }^{106}$ The absence of such a provision in Salini V. Jordan, coupled with the wordings of article 9 (2) of the Italy-Jordan BIT as has been noted by one observer, tells a great deal about the scope of Jordan's consent to arbitration with Italian investors. ${ }^{107}$ In other words, article 9 (2) established that Jordan did not consent to any arbitration of disputes with Italian investors. ${ }^{108}$

The Salini tribunal is justified not only because it correctly highlighted consent as a cornerstone of international law but moreover because of its observance that the MFN clause in BITs should not be interpreted in a manner that opens the gate for "treaty-shopping". ${ }^{109}$ Commenting on the Maffezini decision, the Salini tribunal observed thus: "The current tribunal shares the

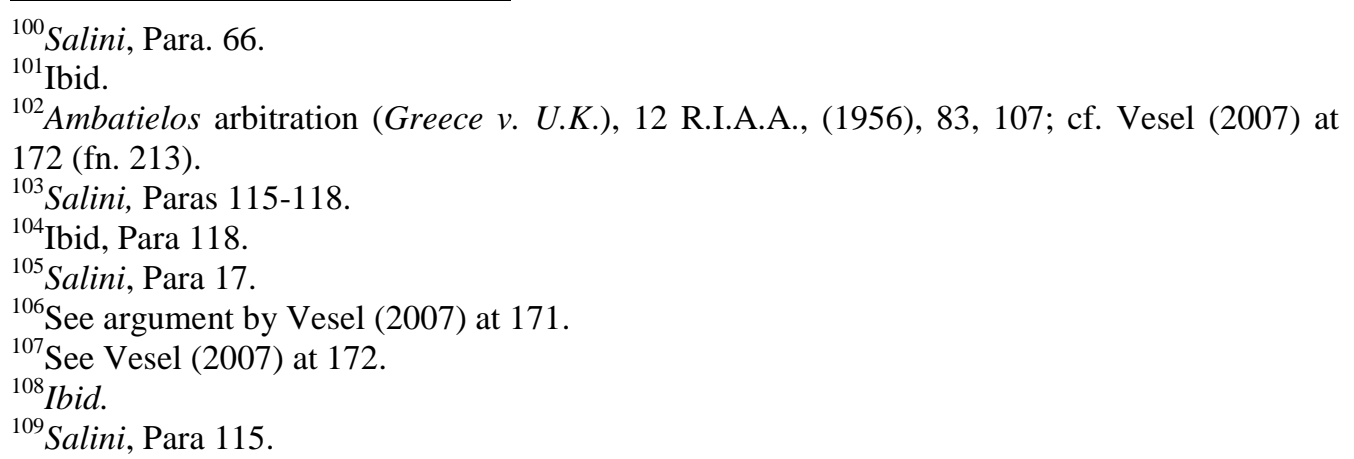


concerns that have been expressed in numerous quarters with regard to the solution adopted in the Maffezini case. Its fear is that the precautions taken by the authors of the award may in practice proof difficult to apply, thereby adding more uncertainties to the risk of treaty-shopping" 110 The Salini tribunal was in effect questioning the basis of the Maffezini caveat which stipulated that interpretations of MFN clauses should not overwhelm public policy concerns. It (the Salini tribunal) was particularly unconvinced such a public policy caveat would be enough to prevent investors from treaty-shopping by exploiting varying MFN provisions. ${ }^{111}$

\section{Plama Consortium Ltd v. Republic of Bulgaria ${ }^{112}$}

The Plama tribunal barely followed the rationale of the Salini decision by arguing in favour of a narrow interpretation of the MFN provision. It was also very sweeping in its critique of the Maffezini caveat.

The case involved a Cypriot investor whose corporation had purchased Nova Plama, a Bulgarian company that owned an oil refinery in Bulgaria. The claimant alleged facing difficult coercive measures from the Bulgarian authorities, which led to material damage on the operations of the refinery. ${ }^{113}$ Basing its claim on Part V of the Energy Charter Treaty (ECT) ${ }^{114}$ and the 1987 Bulgaria-Cyprus BIT, the claimant sought to resolve the dispute before an ICSID jurisdiction rather than through the Bulgarian courts, in order to benefit from the favourable MFN treatment in the Bulgaria-Finland BIT. ${ }^{115}$ The tribunal accepted the claimant's claims based on the ECT but rejected jurisdiction over those claims that were based on the BIT.

The Plama tribunal pointed out that Article 4 of the Bulgaria-Cyprus BIT allowed for a limited form of ad hoc UNCITRAL arbitration (a) only after a domestic court had determined that expropriation had occurred and (b) only to resolve disputes "with regard to the amount of compensation" due to an investor. ${ }^{116}$ It could be implied thus that "the MFN provision of the Bulgaria-Cyprus BIT cannot be interpreted as providing consent to submit a dispute under the BulgariaCyprus BIT to ICSID arbitration...and that the claimant cannot rely on dispute settlement provisions in other BITs to which Bulgaria is a contracting party in the present case." $" 117$

The tribunal went on to assert that the MFN provision would apply to dispute settlement mechanism only when it is so evident in the language of the BIT as well

\footnotetext{
${ }^{110}$ Ibid.

${ }^{111}$ See Chalamish (2009) at 332

${ }^{112}$ See Plama Consortium Limited V. Republic of Bulgaria, ICSID Case No. ARB/03/24, Decision of February 8, 2005.

${ }^{113}$ Ibid, Para 21.

${ }^{114}$ See European Energy Charter Treaty of December 17, 1994, 33 I.L.M., (1995), p. 360.

${ }^{115}$ Bulgaria broadly consented to ICSID jurisdiction in the Bulgaria-Finland BIT. (See Plama, Paras 79, 99).

${ }^{116}$ Plama, Para 26

${ }^{117}$ Ibid, Para 227.
} 
as the specific intent of the parties. ${ }^{118}$ To this effect, it considered the object and purpose of the Bulgaria-Cyprus BIT accordingly:

The object and purpose of the Bulgaria-Cyprus BIT are: 'The creation of favourable conditions for investments by investors of one Contracting Party in the territory of the other Contracting Party. '[...] The Claimant also points to the Maffezini decision in which it is observed: 'dispute settlement arrangements are inextricably related to the protection of foreign investors as they are also related to the protection of rights of traders under treaties of commerce.' Such statements are as such indeniable in their generality, but they are legally insufficient to conclude that the contracting parties to the Bulgaria-Cyprus BIT intended to cover by the MFN provision agreements to arbitrate in other treaties to which Bulgaria (and Cyprus for the matter) is a contracting party. Here, the tribunal is mindful of Sir Ian Sinclair's warning of the 'risk that the placing of undue emphasis on the object and purpose of the treaty will encourage teleological methods of interpretation [which], in some of its more extreme forms, will even deny the relevance of the intention of the parties. "II

Circumstantial evidence was determinant in the tribunal's conclusion. The Cyprus-Bulgaria BIT was signed when Bulgaria was still under communist rule, and did not generally provide for international arbitration as a means of resolving disputes. ${ }^{120}$ It was thus deduced that in the circumstances of the case, the intention of the parties was clearly not to extend dispute settlement mechanism through the MFN provision. ${ }^{121}$ The tribunal equally rejected the claimant's invocation of the MFN clause in the Bulgaria-Finland BIT on the ground that "It is one thing to add to the treatment provided in one treaty more favourable treatment provided elsewhere. It is quite another thing to replace a procedure specifically negotiated by parties with an entirely different mechanism." 122

Meanwhile the Maffezini] and the Siemens tribunals that interpreted silence to imply consent to the dispute settlement mechanism in the MFN clause; the Plama tribunal on the other hand differed and asserted that "one cannot reason $a$ contrario [where an MFN clause is silent] that the dispute settlement provisions must be deemed to be incorporated." "223 In other words, the MFN provision in a basic treaty does not prima facie incorporate in whole or in part to the dispute settlement mechanism in another treaty, unless the MFN clause in the basic treaty "leaves no doubt that the Contracting Parties intended to incorporate them." 124 A broad interpretation of the MFN provision could open the gates for investors to "treaty-shop" between jurisdictions for the best deals. Such a trend is very precarious because it would inevitable subject host states several dispute settlements to which they have not necessarily consented. ${ }^{125}$

\footnotetext{
${ }^{118}$ Ibid, Paras 204, 218, 221 and 223.

${ }^{119}$ Ibid, Para 193.

${ }^{120}$ Ibid, Paras 195-197.

${ }^{121}$ Ibid, Para 198.

${ }^{122}$ Ibid, Para 209.

${ }^{123}$ Ibid, Para 206.

${ }^{124}$ Ibid, Para 223.

${ }^{125}$ Ibid, Para 219.
} 


\section{Dispute Settlement Provision}

On a face value, BITs are designed to achieve two desirable objectives notably, the attraction of inward investments into a host state, and the protection of these investments and other investors' rights in the host state. In the preceding sections, I have examined the common substantive provisions (NT; FET and MFN) of Modern BITs. Beside these, there are also procedural norms to promote and protect FDI flows in[to] the host state.

Modern BITs generally provide for two separate dispute settlement provisions for State-to-state and Investor-to-state arbitrations. Considering the discrepancies of state-to-state arbitration (Diplomatic Protection), foreign investors often opt for direct Investor-State Arbitration (Investment Disputes). While in the former, it is the home state that pleads on behalf of its investors overseas, the latter on the other hand allows foreign investors to directly sue host states for the violation of investors' treaty rights. ${ }^{126}$ Obviously, this is a digression from the erstwhile traditional State-to-State adjudication mechanism. Two important developments in International Investment Law have facilitated this new arbitration, to wit: The establishment of International Centre for the Settlement of Investment Disputes (ICSID) as an arbitral institution in 1965 by the World Bank ${ }^{127}$, and the proliferation of BITs especially since the 1990s, most of which traditionally contain a reference to compulsory Investor-to-State arbitration under ICSID. The chief goal of the institution is to provide a conducive environment for private investment. ${ }^{128}$ According to the Report of the institution's Executive Directors, the primary aim of the ICSID Convention was to create "an institution designed to facilitate the settlement of disputes between states and foreign investors can be a major step forward promoting an atmosphere of mutual confidence and thus stimulating a larger flow of private international capital into those countries which wish to attract it." 129

The Dispute Settlement Provision is seen as the most important aspect of BITs, given that it provides the mechanism through which substantive rules of BITs can be enforced. ${ }^{130}$ Without the dispute settle clause, BITs would "represent merely an abstract declaration of the importance of FDI and its protection."131 Thanks to the provision, international law has undergone a completely new shift in favour of a strong recognition on non-state actors, advancing the rights of private parties to directly pursue claims under an international treaty, without appealing to their home state for assistance in pursuing such claims. ${ }^{132}$

\footnotetext{
${ }^{126}$ Infect, Diplomatic Protection adjudication can be characterized as Inter-Governmental Disputes. It generally provides for purely ad hoc arbitration, governed by the specific treaty rules. See Petrochilos, (2004) at 246-257. See also Dolzer \& Stevens (1995) at 119.

${ }^{127}$ See Convention on the Settlement of Investment Disputes between States and Nationals of Other States (ICSID), (1965), 575 United Nation Treaty Series (U.N.T.S) 159, 4 Int'l Legal Materials 524 (1965).

${ }^{128}$ See Dolzer \& Stevens (1995) at 20

${ }^{129}$ ICSID Convention, Report of the Executive Directors, Regulations \& Rules, at 40.

${ }^{130}$ See Freeman (2009) at 9.

${ }^{131}$ See Chalamish (2009) at 316.

${ }^{132}$ See Dolzer \& Stevens (1995) at 119; See also Freeman (2009) at 9 and Chalamish (2009) at 341.
} 


\section{Conclusion}

It is sometimes hard to see how and why developing countries are in such a mad rush for BITs-because the treaties' clauses pay little regard to the economic sovereignty of the host nations. Instead, they are focussed on magnanimous investors' rights and nearly ignoring investors' obligations, thereby effectively "preserving the dominance of investment interests in developing countries."133 The popularity of the treaties lie in the fact that host states agree to grant foreign investors with guarantees for National treatment vis-à-vis their own home investors; Fair and Equitable Treatment; Most Favoured Nation Treatment vis-àvis investors of other countries that are not party to the treaty, Free Transfer and Repartition of Profits, Compensation in the event of an Expropriation and Dispute Settlement Mechanism which allows foreign investors to bring claims against the host in an International Investment Arbitration Tribunal, in response to any violations of BITs obligations. ${ }^{134}$

Most of these guarantees turn to imply that foreign investors can potentially challenge virtually any public policy regulation by the host state that they construe to affect to affect them. ${ }^{135}$ Infect, BITs provisions generally touch on a common set of investment issues. Recent jurisprudence exemplifies the tendency of foreign investors relying almost always on a broad reading of BITs clauses in order to base their claims. Although some of these tribunals have actually concurred to such interpretations (Pope \& Talbot v. Canada, Marvin Roy Feldman, Maffezini and the Siemens), caution has also been exercised to prevent the temptation of "treatyshopping" (Mondev, S.D. Myers, Salini and Plama). Tribunals have demonstrated a willingness to treat every case on its merits. All the cases have typified that fact that the validity of a claim is chiefly determined by the language of the BITs clause. Where the scope of the provision expressly provides for limitation, tribunals must give it such an effect (Salini and Plama). The intention of the parties is paramount.

\section{References}

Adlung, R. \& M. Molinuevo (2008). 'Bilateralism and Services Trade: Is There Fire Behind the (BIT-) Smoke', in Journal of International Economic Law 11: 365-409.

Brower, H.Ch. (2001). 'Investor - State Disputes under NAFTA: The Empire Strikes Back' in Col. J. Transn. L. 40:43-88.

Brown, Ch.W. (2009). 'Investment Arbitration as the New Frontier', 28 The Arbitrator and Mediator 28(1):59-69.

Brownlie, I. (2008). Principles of Public International Law, $7^{\text {th }}$ ed. Oxford: Oxford University Press.

Busse, M., Königer, J. \& P. Nunnenkamp, (2010). 'FDI Promotion through Bilateral Investment Treaties: More Than a Bit?' in Review of World Economics 146:147-177.

\footnotetext{
${ }^{133}$ See Chalamish (2009) at 310.

${ }^{134}$ See Carlos (2004) at 312 and Chalamish (2009) at 310.

${ }^{135}$ See Neumayer \& Spess (2005) at 1571.
} 
Campbell, McLachlan, C., Shore, L. \& M. Weiniger (2007). International Investment Arbitration: Substantive Principles. (Oxford International Arbitration Series).Oxford: Oxford University Press. $2^{\text {nd }}$ ed. 2017.

Carlos, G. (2004). 'All the Other Dirty Little Secrets: Investment Treaties, Latin America, and the Necessary Evil of Investor-State Arbitration' in Florida Journal of International Law 16: 301-370.

Chalamish, E. (2009). 'The Future of bilateral Investment Treaties: A De Facto Multilateral Agreement?' in Brook. J. Int'l L. 34:303-354.

Chung, O. (2007). 'The Lopsided International Investment Law Regime and Its Effect on the Future of investor-State Arbitration ' in Va. J. Int'l L. 47: 953-958.

Convention on the Settlement of Investment Disputes between States and Nationals of Other States (ICSID), (1965), 575 United Nation Treaty Series (U.N.T.S) 159, 4 Int'l Legal Materials 524 (1965).

Dolzer, R. (2005). 'National Treatment: New Developments', Presentation for the ICSID, OECD AND UNCTAD co-organized Symposium, (Paris, Dec. 12, 2005).

Dolzer, R. \& M. Stevens (1995). Bilateral Investment Treaties. The Hague/Boston/ London: Martnus Nijhoff.

Fietta, S. (2005). 'Most Favoured Nation Treatment and dispute resolution under Bilateral Investment Treaties: A turning point' in International Arbitration Law review (2005) 131-138.

Franck, D.S. (2005). 'The Legitimacy Crisis in Investment Arbitration: Privatizing Public International Law Through Inconsistent Decisions' in Fordham Law Review 73: 1521-1625.

Freeman, N.W. (2009). The Determinants of Investor-State Disputes: Institutional Capacity and Compliance with Bilateral Investment Treaties', Paper presented at the annual meeting of the Southern Political Science Association, Hotel Intercontinental, New Orleans, LA, $7^{\text {th }}$ Jan. 2009 [Unpublished]

Freyer, D.H. \& D. Herlihy, (2005) 'Most-Favoured-Nation Treatment and Dispute Settlement in Investment Arbitration: Just How "Favoured" is "Most-Favoured"? ICSID Rev. in Foreign Inv. L. J., 20(1)58-83

Gaillard, E. (2005). 'Establishing Jurisdiction Through a Most-Favoured-Nation Clause' in New York Law Journal 233, No. 105, 1-9.

Gann, B.P. (1985). 'The US Bilateral Investment Treaty Program', in Stanford J. of Int'l L. 21: 373-376.

Garcia, C.G. (2004). 'All the Other Dirty Little Secrets: Investment Treaties, Latin America, and the Necessary Evil of Investor-State Arbitration', in Florida Journal of International Law 16: 301-370

Goodman, C.L. (2007). 'Unchartered Waters: Financial Crisis and Enforcement of ICSID Awards in Argentina' in University of Pennsylvania Journal of International Economic Law 28:449-486.

Greig, T.R., Annacker, C. \& R. Zaide (2008). 'How Bilateral Investment Treaties can protect Foreign Investors in the Arab World or Arab investors abroad' in Journal of International Arbitration 25:257-273.

Guzman Z., Elkins, A.T. \& B. Simmons (2006). 'Competing for Capital: The Diffusion of Bilateral Investment Treaties 1960 and 2000' in International Organization, 60:811846.

Guzman, A. (1998). 'Why LDCs Sign Treaties That Hurt Them: Explaining the Popularity of Bilateral Investment Treaties' in Virginia Journal of International Law 38:639688. 
Hamilton, C. \& P. Rochwerger (2005). 'Trade and Investment: Foreign Direct Investment through Bilateral and Multilateral Treaties' in New York International Law Review 18:1-59.

Havana Charter for an International Trade Organization (1948).

Houde, M-F (2004). 'Most Favoured Nation Treatment in International Investment Law', OECD Working Paper on International Investment, Number 2004/2, OECD Publishing. http://dx.doi.org/10.1787/518757021651

Kill, T. (2007). 'Don't Cross the Streams: Past and Present Overstatement of Customary International Law in Connection with Conventional Fair and Equitable Treatment Obligations', in Michigan Law Review 106:853-880.

Kurtz, J. (2002). 'A General Investment Agreement in the WTO? Lessons from Chapter 11 of NAFTA and the OECD Multilateral Agreement on Investment' in University of Pennsylvania Journal of International Economic Law 23:713-790.

Malnik, M. (2009). 'Fair and equitable treatment', International Institute for Sustainable Development (IISD), (Working Paper series, Bulletin \#3, September 2009). "Fairness" and "Equity" and fundamental principles recognized by virtually every legal system.

Mann, A.F. (1981). 'British Treaties for the Promotion and Protection of Investments', in B.Y.I.L 52: 241-254.

Mann, H. \& K. von Moltke (2004). 'Protecting Investor Rights and the Public Good: Assessing NAFTA's Chapter 11' Background Paper to the ILSD Tri-National Policy Workshops, Mexico City: March 13; Ottawa March 18; Washington: April 11, 2003.

Nash, M. (1993). 'Contemporary Practice Of The United States Relating To International Law-Bilateral Investment Treaties' in American Journal of International Law 87: 433-441.

Neumayer, E. \& L. Spess (2005). 'Do bilateral investment treaties increase foreign direct investment to developing countries? 'in World Development Journal 33:1567-1585.

Newcombe, A. \& L. Paradell (2008). Law and Practice of Investment Treaties: Standards of Treatment/ The Hague: Kluwer Law International.

Paterson, R.K. (1991). 'Canadian Investment Promotion and Protection Treaties' 29 on Canadian YB of Int'l L. 29: 373-390.

Petrochilos, G. (2004). Procedural Law in International Arbitration, (Oxford: Oxford University Press.

Radi, Y (2007). 'The application of the most favoured nation clause to the dispute settlement provisions of bilateral investment treaties: Domesticating the Trojan Horse' 18 EJIL, doi: 10.1093/ejil/chm031

Ranjan, P. (2007). 'Bilateralism, MFN and TRIPS: Exploring Possibilities of Alternative Interpretation' in International Trade Law and Regulation 13: 67-78.

Robin, P.M. (1984). "The BIT Won't Bite: The American Bilateral Investment Treaty Program", in American University Law Review, 33:931-958.

Salacuse, J.W. \& N.P. Sullivan (2005), 'Do BITs Really Work? An Evaluation of Bilateral Investment Treaties and Their Grand Bargain', in Harvard International Law Journal 46: $67-130$.

Salacuse, J.W. (1990). 'BIT by BIT: The Growth of Bilateral Investment Treaties and their Impact on Foreign Investment in Developing Countries', in The International Lawyer, 24: 655-675.

Schill, S.W. (2009). 'Multilateralizing Investment Treaties Through Most-Favoured-Nation Clauses', in Berk. J. of Int'l L. 27(2):496-569.

Schreuer, C. (2005). 'Fair and Equitable Treatment in Arbitral Practice', in Journal of World Investment and Trade, 6:357-386. 
Tobin, J. \& S. Rose-Ackerman (2005). 'Foreign direct investment and the business environment in developing countries: The impact of bilateral investment treaties 'in Yale Law School Center for Law, Economics and Public Policy Research Paper No. 293. doi:10.2139/ssrn.557121.

Trebilcock, J.M. \& K.S. GIRI (2004). Handbook of International Trade, Vol. I, E. Kwan Choi \& James C. Hartigan (Eds). Oxford: Blackwell.

Trebilcock, J.M. \& R. Howse (2005). The Regulation of International Trade. $3^{\text {rd }}$ ed. New York: Routledge.

Tudor, I. (2009). 'The Fair and Equitable Treatment Standard in the International Law of Foreign Investment. 2008, Oxford: Oxford University Press' in EJIL 20:229-239.

UNCTAD 1999, Fair and Equitable Treatment (UNCTAD Series on Issues in International Investment Agreements, 1999) UNCTAD/ITE/IIT/11 (Vol. III) ((United nations, New York and Geneva)

UNCTAD 2005, Investor-State Disputes Arising from Investment Treaties: A Review, (UNCTAD series on International Investment Policies for Development, 2005)

UNCTAD 2008, Recent Developments in International Investment Agreements (2007June 2008) 2 IIA Monitor (2008), U.N. Doc. UNCTAD/WEB/DIAE/IA/2008/1.

UNCTAD 2009, 'Latest Developments in Investor- State Dispute Settlement', IIA Monitor No. 1 (2009), (United nations, New York and Geneva)

Vandevelde, J.K. (1996). Book Review and Note, 'Bilateral Investment Treaties, by Rudolf Dolzer \& Margrete Stevens' in American Journal of International Law 90(3): 545547. doi:10.2307/2204091

Vandevelde, J.K. (1998). 'Investment Liberalization and Economic Development: The role of Bilateral Investment Treaties', in Colum. J. Trans. L. 36: 501-528.

Vesel, S. (2007). 'Clearing a path through a tangle jurisprudence: Most-Favoured -Nation clause and dispute settlement provisions in Bilateral Investment Treaties', in Yale Journal of International Law, 32(1):125-189.

Wong, J. (2008). 'The Application of the Most-Favoured-Nation Clauses to Dispute Resolution Provisions in Bilateral Investment Treaties', in 3 Asian J. W.T.O. \& Int'l Health L. \& Pol'y, 3:171-192.

Yackee, J.B. (2009). 'Pacta Sunt Servanda and State Promises to Foreign Investors before Bilateral Investment Treaties: Myth and Reality' in Fordham International law Journal 32:1550-1613.

Yannaca-Small, C. (2004). 'OECD, Fair and Equitable Treatment Standard in International Investment Law' (Working papers on International Investment, Number 2004/3, Paris, OECD, 2004).

Ziegler, A.R. (2008). 'Most-Favoured-Nation (MFN) Treatment', in: A. Reinisch (ed.), Standards of Investment Protection. Oxford: Oxford University Press, at pp. 29-86.

Ziegler, A.R. (2010). 'The Nascent International Law on Most-Favoured-Nation (MFN) Clauses in Bilateral Investment Treaties (BITs)', in Eur. YB of Int'l Econ. L., 1:77101.

\section{Cases}

Emilio Agustion Maffezini v. Kingdom of Spain, ICSID Case No. ARB/97/7, Decision of January 25, 2000.

LFH Neer \& Pauline Neer (USA) v. United Mexican States (1926) IV RIAA 60.

Marvin Roy Feldman Karpa v. United Mexican States, ICSID Case No. ARB(AF)/99/1, (16 December 2002). 
Mondev International Ltd v. United States, Award, ICSID Case No ARB(AF)/99/2; IIC 173, (2002).

Plama Consortium Limited v. Republic of Bulgaria, ICSID Case No. ARB/03/24, Decision of February 8, 2005.

Pope \& Talbot v. Canada, Award, April 10th 2001, 7 ICSID Reports.

Ronald S. Lauder v. The Czech Republic, Final Award, ${ }^{\text {rd }}$ Sep. 2001, 9 ICSID Reports.

S.D. Myers Inc. v. Canada, First Partial Award of November 13, 2000 (Hunter, Chiasson, Schwartz), 40 ILM 1408 (2001).

Salini Construttori S.p.A and Italstrade S.p.A v. The Hashemite Kingdom of Jordan, ICSID Case No. ARB/02/13, Decision of November 15, 2004.

Siemens A.G. v. The Argentina Republic, ICSID Case No. ARB/02/8, Decision of August 3, 2004.

The Ambatielos case, U.N. Reports of Int'l Arbitral Awards, 1963

The Treaty between the Federal Republic of Germany and Pakistan for the Promotion and Protection of Investments (Germany v. Pakistan (1959)), 457 U.N.T.S. 23. 